UDC 338.5:65:005.93

O. Yakimov, DSc, Prof.,

G. Zadorozhko, $\mathrm{PhD}$, Assoc. Prof.,

L. Bovnegra, PhD, Assoc. Prof.,

S. Beznos,

V. Balan

Odessa National Polytechnic University, 1 Shevchenko Ave., Odessa, Ukraine, 65044; e-mail: dlv5@ukr.net

\title{
POSSIBLE WAYS TO REDUCE THE COST OF GRINDING PROCESS OF PRODUCTS WITH INTERMITTENT CIRCLES
}

\begin{abstract}
О.О. Якімов, Г.І. Задорожко, Л.В. Бовнегра, С.В. Безнос, В.О. Балан. Можливі шляхи зниження витрат на шліфувальну обробку виробів переривчастими кругами. Шліфування в більшості випадків є заключною операцією механічної обробки, на якій формується якість поверхневого шару виготовленої деталі. Стабільну якість поверхневого шару при шліфуванні та високу продуктивність можна забезпечити, застосовуючи шліфувальні круги з переривчастою робочою поверхнею. Мета наукового дослідження - виявлення шляхів зниження витрат на виготовлення переривчастих шліфувальних кругів. Теоретичні дослідження проводилися на базі теорії різання металів, теорії коливань. Собівартість шліфувальної обробки кругами 3 переривчастою робочою поверхнею багато в чому залежить від форми й розмірів геометричних елементів, з яких полягає робоча поверхня абразивного інструмента, і від умов роботи кругів. Виявлені основні шляхи зниження витрат на шліфувальну обробку переривчастими кругами. Інженерні методики, засновані на результатах проведених досліджень, використовуються на Луцькому автомобільному заводі.

Ключові слова: собівартість обробки, переривчасті круги, глибинне шліфування

O. Yakimov, G. Zadorozhko, L. Bovnegra, S. Beznos, V. Balan. Possible ways to reduce the cost of grinding process of products with intermittent circles. Grinding in most cases is the final operation of machining, on which the quality of the surface layer of the manufactured part is formed. Stable quality of the surface layer during grinding and high productivity can be ensured by using grinding wheels with a discontinuous working surface. The purpose of research is to identify the ways to reduce the cost of manufacturing intermittent grinding wheels. The results of the studies are applied in engineering methods for calculating the structural elements of interrupted abrasive wheels. Theoretical studies were carried out on the basis of the theory of metal cutting, the theory of oscillations. The cost of grinding in circles with a discontinuous working surface depends to a large extent on the shape and dimensions of the geometric elements that make up the working surface of the abrasive tool and the working conditions of the circles. The main ways of reducing the cost of grinding with presprouted circles are revealed. Engineering methods based on the results of conducted research are used at the Lutsk Automobile Plant.

Keywords: processing propriety, intermittent circles, deep grinding
\end{abstract}

Introduction. The development of machine-building production is impossible without the use of science-intensive technologies, since they make it possible to reduce the cost of processing and ensure high-quality manufacturing of parts. One way to reduce cost is to reduce processing cost for manufacturing cutting tools and tooling.

Formulation of the problem. The most common way to finish the hardened parts is grinding. Grinding is accompanied by complexes of mechanical and thermal effects on the machined surfaces of parts leading to a significant change in the physical and mechanical state from the surface layer and, as a consequence, to a decrease in the service life of the products. The possibility of obtaining highquality surfaces with properties that improve the performance of products can be provided using grinding wheels with intermittent work surfaces. These circles reduce the temperature in the cutting zone and have an increased cutting capacity compared to the continuous ones, which makes it possible to reduce the cost of processing due to the intensification of the cutting regimes.

At present, circles with a discontinuous working surface are almost not used, since there are a number of unsolved problems of a mechanical nature that arise during their manufacture and operation. One of these reasons is the lack of recommendations for the effective use of these tools. Therefore, the problem of reducing costs for grinding processing of products is tried to solve in other ways.

Analysis of recent research and publications. A method is known for calculating the cost of processing when grinding hard alloys with periodic electro erosive effects on the working surface of DOI: 10.15276/opu.1.54.2018.05

(c) 2018 The Authors. This is an open access article under the CC BY license (http://creativecommons.org/licenses/by/4.0/). 
the wheel [1]. This method allows you to calculate the optimum stability of the wheel when grinding by the criterion of the minimum specific cost of processing. One of the main criteria for the effectiveness of the technological process of machining is its productivity.

Works [2-4] are devoted to the identification of ways to improve productivity in grinding. The study of the energy intensity of the intermittent grinding process was conducted, which showed that with intermittent grinding, a significant reduction in the specific energy consumption is achieved compared to conventional abrasive grinding. It is established that the process of intermittent grinding is a

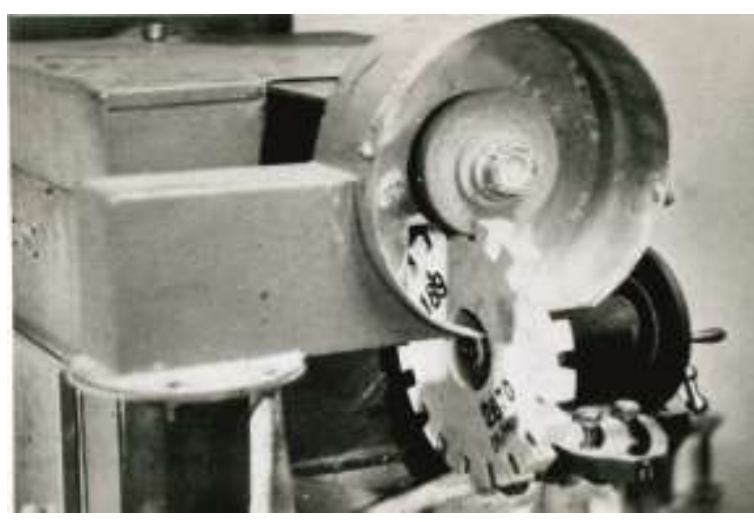

Fig.1. Cutting the grooves on the grinding wheel on the grinding machine promising resource-saving process. However, the wide introduction of circles with a discontinuous working surface in engineering enterprises of Ukraine is constrained by the large costs of their manufacture [5].

This is due to the imperfection of technologies for the formation of depressions on the grinding wheel.

The technology of manufacturing discontinuous circles on a ceramic bond is reduced to slotting grooves on grinding machines equipped with dividing devices (Fig. 1).

The disadvantages of this technology are low productivity, and the allocation of a large amount of abrasive dust, resulting in rapid wear of the guides in the sharpening machine and contributing to the emergence of occupational disease of the sharpener - silicosis.

A more progressive technology for the production of intermittent circles is known with the aid of a shot blasting machine. The technology provides for blasting with a shot (diameter $0.5 \ldots 0.8 \mathrm{~mm}$ ) of a continuous grinding wheel on which a template is fixed. The jet shot knocks the cavity on a continuous circle. [6] The disadvantage of this method is the impossibility of formation of cavities of small width. The technology of manufacturing of intermittent circles on the ceramic bond by more efficient pressing method is not developed.

The purpose of the research is to identify ways to reduce the cost of manufacturing intermittent grinding wheels and to justify the most promising areas of their effective use at machine-building enterprises in Ukraine.

Statement of the main material. When grinding with discontinuous circles, the hardness of the elastic system of the surface grinding machine changes periodically. This leads to the appearance of parametric resonance. As a result of the appearance of large-amplitude oscillations in the elastic system of the machine, the abrasive intermittent circle begins to work in the mode of catastrophic wear. This is accompanied by burns and waviness on the treated surfaces.

In Fig. 2 shows the zones of parametric instability of the elastic system of a surface grinding machine (hump) and aria of stable grinding (intervals between humps). These zones are calculated in the intervals of variation of the numbers of the cutting protrusions $0 \leq n \leq 160$ (a) and the values of the ratio of the dimensions of the depressions $l_{2}$ to the lengths of the protrusions $l_{1} \quad 0,325 \leq l_{2} / l_{1} \leq 0,450$ (b) according to the following formulas:

$$
\begin{gathered}
|L|>\frac{1+M}{2}, \\
L=\frac{e^{-h\left(\tau_{1}+\tau_{2}\right)}}{h\left(k_{2}+h \sin 2 k_{2} \tau_{1}\right)}\left[k_{1}^{2} \sin k_{1} \tau_{1} \sin k_{2} \tau_{2}-2 \cdot k_{1} \cdot k_{2} \cdot \cos k_{2} \tau_{1} \cdot \cos k_{1} \tau_{1} \cdot \cos k_{2}\left(\tau_{1}+\tau_{2}\right)-\right. \\
\left.-k_{2}^{2} \sin k_{1} \tau_{1} \sin \left(2 \cdot k_{2} \tau_{1}+k_{2} \tau_{2}\right)\right],
\end{gathered}
$$




$$
M=\frac{k_{1} k_{2} e^{-2 h\left(\tau_{1}+\tau_{2}\right)} \cos \left(2 \cdot k_{2} \cdot\left(\tau_{1}+\tau_{2}\right)\right)}{h\left(k_{2}+h \sin 2 k_{2} \tau_{1}\right)},
$$

where $\tau_{1}, \tau_{2}$ - the times of passage of protrusions and hollows over the surface of the working surface of the discontinuous circle, $\mathrm{s}$;

$$
\begin{aligned}
& k_{1}=\sqrt{\frac{C_{0}}{m}+\frac{C_{0} \cdot\left(\frac{t_{l}}{t_{a}}-1\right)}{2 \cdot m}-h^{2}}, \quad k_{2}=\sqrt{\frac{C_{0}}{m}-\frac{C_{0} \cdot\left(\frac{t_{l}}{t_{a}}-1\right)}{2 \cdot m}-h^{2},} \\
& t_{l}-\text { cutting depth, established by the limb, } \mathrm{m} ; \\
& t_{a}-\text { actual depth of cut, } \mathrm{m} ; \\
& C_{0}-\text { reduced rigidity of the elastic system of the machine, } \mathrm{N} / \mathrm{m} ; \\
& h-\text { a quantity characterizing the extinction of oscillations in time, } 1 / \mathrm{s} ; \\
& m-\text { reduced mass of grinding wheel, }\left(\mathrm{Ns}^{2}\right) / \mathrm{m} \text {. }
\end{aligned}
$$

Calculations were carried out for different values of reduced rigidity $C_{0}: C_{0}=0,3 \cdot 10^{6} \mathrm{~N} / \mathrm{m}$, $C_{0}=2 \cdot 10^{6} \mathrm{~N} / \mathrm{m}$ and $C_{0}=3,5 \cdot 10^{6} \mathrm{~N} / \mathrm{m}$ (Fig. 2).
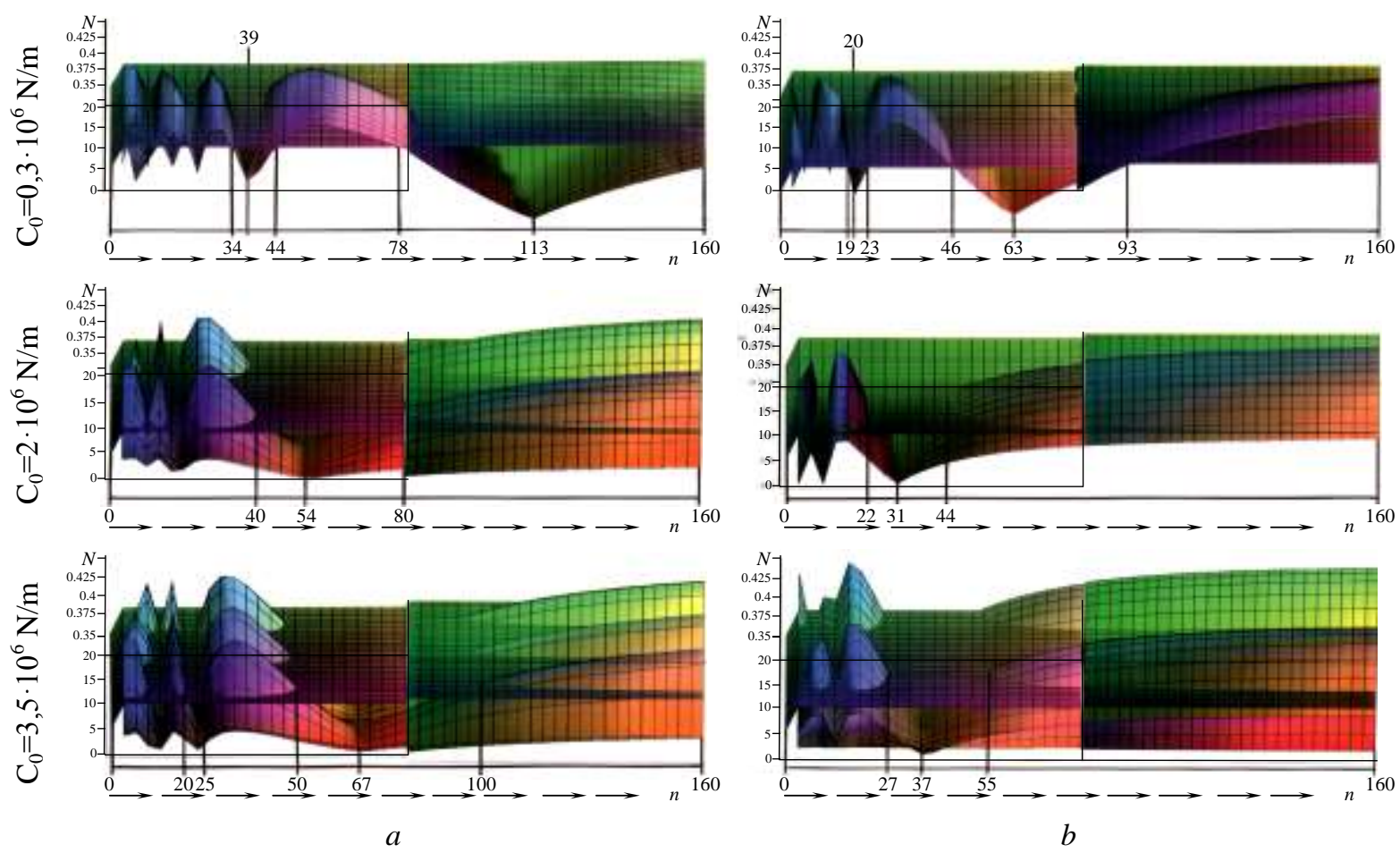

Fig. 2. Zones of parametric instability of the elastic system of the machine (hump), constructed for $V_{\text {cir }}=25 \mathrm{~m} / \mathrm{s}$ (a), $V_{\text {cir }}=40 \mathrm{~m} / \mathrm{s}\left(\right.$ b) at $C_{0}=0.3 \cdot 10^{6} \mathrm{~N} / \mathrm{m}, C_{0}=2 \cdot 106 \mathrm{~N} / \mathrm{m}, C_{0}=3.5 \cdot 106 \mathrm{~N} / \mathrm{m}$

It can be seen from Fig. 2 that with increasing rigidity of the elastic system $C_{0}$, the dimensions of the regions of stable grinding, measured along the axis $n$, expand, and the regions themselves shift in the direction of increasing the number of slits on the circle. With increasing speed $V_{c i r}$, the dimensions of the regions of stable grinding, measured along the axis $n$, narrow.

Analysis of Fig. 2 made it possible to plot graphs $\Delta n=f\left(C_{0}\right)$ and $n_{c p}=f\left(C_{0}\right)$ for the circumferential velocities of the circle $V_{\text {cir }}=25 \mathrm{~m} / \mathrm{s}$ and $V_{\text {cir }}=40 \mathrm{~m} / \mathrm{s}$, where: $\Delta n$ - interval of numbers of 
cutting protrusions on a discontinuous circle defining the width of the zone of stable grinding; $n_{c p}-$ the number of cutting projections corresponding to the minimum value $L$ in the interval $\Delta n$. The graphs are shown in Fig. 3.

From the analysis in Fig. 3 (b) it follows that, due to the cutting speed $V_{c i r}$, it is possible to achieve a significant reduction in the number of slits in intermittent circles.

Reducing the number of slits on intermittent circles can be achieved
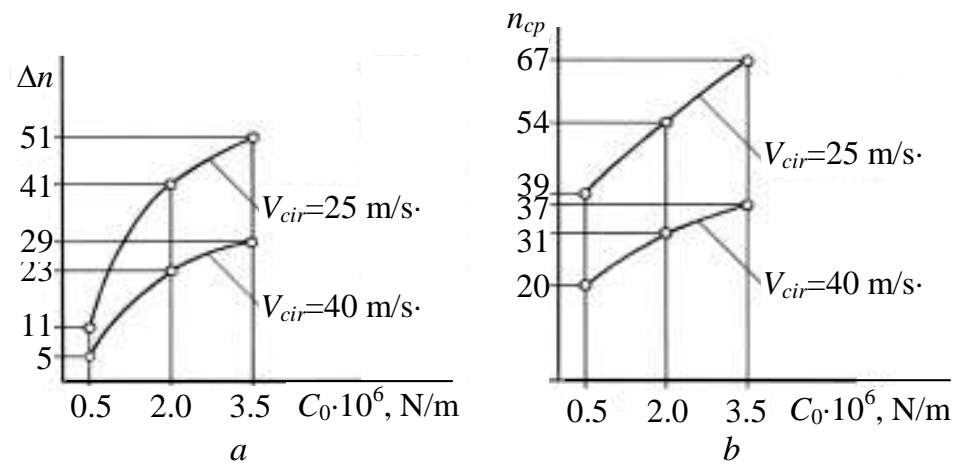

Fig 3. Graphs showing the nature of the increase $\Delta n(a)$ and $n_{c p}(b)$ with increasing the given rigidity $C_{0}$ of the elastic

system of the machine for $V_{\text {cir }}=25 \mathrm{~m} / \mathrm{s}$ and $V_{\text {cir }}=40 \mathrm{~m} / \mathrm{s}$ by increasing the coefficient of discontinuity $K_{d i s}$, numerically equal to the ratio of the extent of the cavity $l_{2}$ to the length of the projection $l_{1}$. This follows from the analysis of Fig. 4 , in which the regions of parametric instability of the elastic system of the machine look like ellipses stretched in the direction of their large axes.

And with an increase in the number of cutting protrusions, the degree of elongation of the ellipses increases. The intervals between the ellipses are the zones of stable operation of the elastic system of the machine tool. The boundaries of these zones are curves VI, V, IV, III, II, I. From the nature of these curves it can be seen that a decrease in the number of slits on the grinding wheel can be achieved by increasing their dimensions (by increasing the intermittence coefficient $K_{d i s}=l_{2} / l_{1}$ ). For example, with an increase in the coefficient of discontinuity $K_{\text {dis }}$ from 0.3 to 1.0, the number of depressions $n$ on the circle decreases from 45 to 30 .

And with an increase in the number of cutting protrusions, the degree of elongation of the ellipses increases. The intervals between the ellipses are the zones of stable operation of the elastic system of the machine tool. The boundaries of these zones are curves VI, V, IV, III, II, I. From the nature of these curves it can be seen that a decrease in the number of slits on the grinding wheel can be achieved by increasing their dimensions (by increasing the intermittence coefficient $K_{\text {dis }}=l_{2} / l_{1} \quad K_{\text {dis }}=l_{2} / l_{1}$ ). For example, with an increase in the coefficient of discontinuity $K_{d i s}$ from 0.3 to 1.0 , the number of cavities on the circle decreases from 45 to 30 .

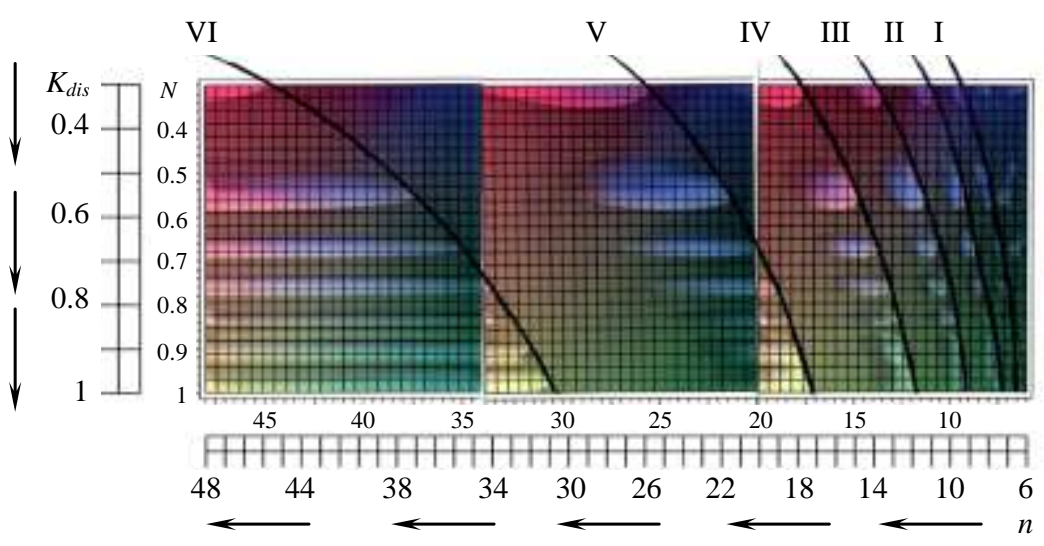

Fig. 4. Areas of parametric instability of the elastic system of the machine tool in the form of ellipses and the boundary of zones of stable work in the form of curves VI, V, IV, III, II, I 
By reducing the number of cavities is possible to achieve a significant reduction in the cost of manufacture of discontinuous circles.

Thus, by calculations using formulas $(1,2,3)$ it is established that it is possible to reduce the number of cavities on grinding wheels and, as a consequence, to reduce the cost of manufacturing them by increasing the coefficient of discontinuity $\left(K_{d i s}=l_{2} / l_{1}\right)$ and cutting speed $V_{\text {cir }}$.

With increasing circumferential velocity of the circle $V_{\text {cir }}$, its wear decreases (Fig. 5, 6) [7]. Fig. 5,6 shows the data obtained during grinding, which was performed in the following modes: $V_{\text {det }}=10$ $\mathrm{m} / \mathrm{min} ; t=0,03 \mathrm{~mm}$ - table travel with different circumferential velocities of the circle: $V_{\text {cir }}=16 \mathrm{~m} / \mathrm{s}$ (curve 1); $V_{\text {cir }}=25 \mathrm{~m} / \mathrm{s}$ (curve 2); $V_{\text {cir }}=35 \mathrm{~m} / \mathrm{s}$ (curve 3).
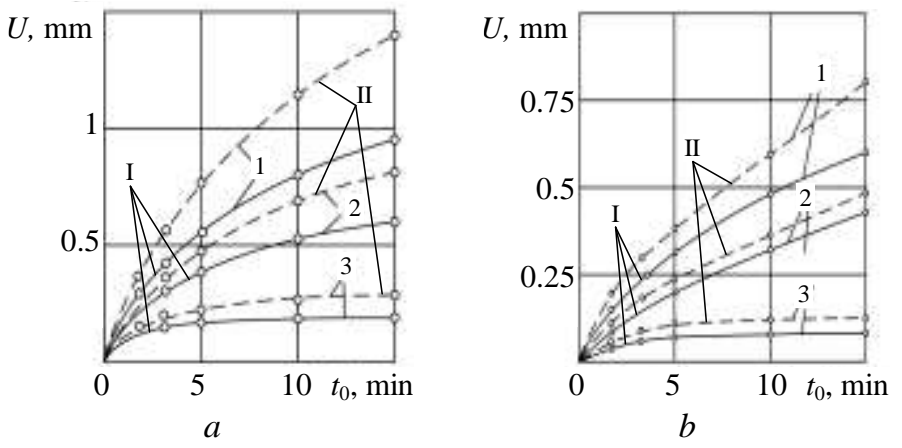

Fig. 5. Dependence of the circumferential speed of the wheel on its wear without preliminary weighing of the grinding unit (a) and with preliminary weighing (b) $P=25 \mathrm{~kg}$ : continuous grinding (I); intermittent grinding (II)

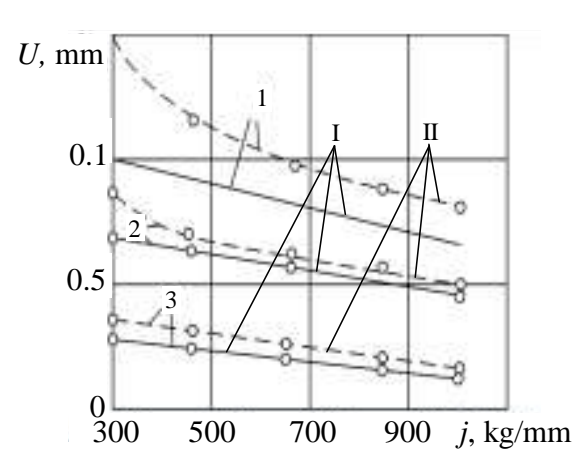

Fig. 6. Dependence of linear wear and a circle on the specific rigidity of the grinding unit: continuous grinding (I); intermittent grinding (II)

When grinding with great depth and insufficient peripheral speed of the circle, the loss of grains in work increases and, as a consequence, the correct geometric shape of the circle is broken. In this process, vibrations occur during the grinding process and the circle must be frequently corrected to restore the shape. To increase the dimensional stability of the wheels, it is necessary to increase the circumferential speed of the circle to $40 \mathrm{~m} / \mathrm{s}$ and to provide in the machines the possibility of maintaining the constant circumferential velocity of the wheel as it wears out. Dependences of dimensional wear on the time of blunting and various circumferential velocities of the circle during grinding without load of the spindle unit and with its load are shown in Fig. 5.

The increase in circumferential speed of the circle sharply reduces its wear, which is explained by a decrease in the load on the cutting grain. The dimensional wear of discontinuous circles throughout

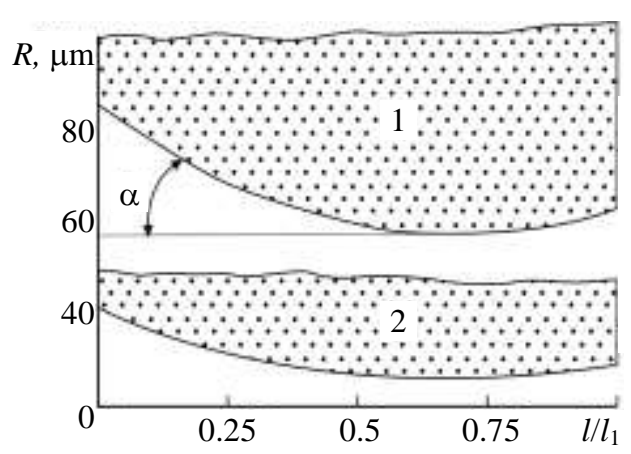

Fig. 7. Character of the wear of the cutting edge of the elboric discontinuous disc at different time intervals: $1-\tau=7 \mathrm{~min}$;

$$
2-\tau=2 \min
$$
the investigated range of cutting speeds increases in comparison with continuous grinding by $1.3 \ldots 1.5$ times, which can be explained by the increased self-sharpening of the discontinuous abrasive tool.

The increase in rigidity during grinding by discontinuous circles at circumferential speeds of 16 and $25 \mathrm{~m} / \mathrm{s}$ reduces the wear according to the curvilinear law, and when grinding at speeds of $35 \mathrm{~m} / \mathrm{s}$ and at all speeds with a continuous circle - along a straight line (Fig. 6).

Fig. 7 shows enlarged profiles of the cutting protrusions of the elboric discontinuous circle 1 A1 $200 \times 75 \times 5 \times 20$ КР 160/125 58100 after a 2-minute and 7-minute processing of samples of steel P6M5 with a width of $8 \mathrm{~mm}$, length of $150 \mathrm{~mm}$ on a surface grinding machine of the ЗГ $71 \mathrm{M}$ method by plunging. 
It is established that, after the run-in, the profiles of the cutting protrusions of the circle acquire a constant shape. Regardless of the grinding modes, the angle of attack $\alpha$ of the front zone of the discontinuous circle KP $160 / 125$ B8 100 with 12 protrusions $\left(l_{1}=45 \mathrm{~mm}, l_{2}=20.5 \mathrm{~mm}\right)$ after 4 ...5minute grinding period is $6 \ldots 12^{\circ}$.

The change in the linear wear of discontinuous circles as grinding of P6M5 steel made it possible to estimate the consumption of the elbor under various modes of ground grinding (see Table).

Specific wear of interrupted elbor wheels

\begin{tabular}{c|c|c|c|c|c|c|c|c}
\hline \multirow{4}{*}{$\begin{array}{c}\text { Weight of grinding } \\
\text { metal, g }\end{array}$} & $\begin{array}{c}\text { Mode } 1: t=0,5 \mathrm{~mm}, \\
V_{\text {det }}=0,3 \mathrm{~m} / \mathrm{min}, \text { liquid coolant }\end{array}$ & 9 & 18 & 27 & 36 & 45 & 54 & 63 \\
\cline { 2 - 9 } & $\begin{array}{c}\text { Mode } 2: t=1,0 \mathrm{~mm}, \\
V_{\text {det }}=0,1 \mathrm{~m} / \mathrm{min}, \text { liquid coolant }\end{array}$ & 9 & 18 & 27 & 36 & 45 & - & - \\
\cline { 2 - 8 } & $\begin{array}{c}\text { Mode } 3: t=0,03 \mathrm{~mm}, \\
V_{\text {det }}=6 \mathrm{~m} / \mathrm{min}, \text { liquid coolant }\end{array}$ & 11 & 22 & 26 & 44 & 56 & 67 & 87 \\
\hline $\begin{array}{c}\text { Mode } 1: t=0,5 \mathrm{~mm}, \\
V_{\text {det }}=0,3 \mathrm{~m} / \mathrm{min}, \text { liquid coolant }\end{array}$ & 4.16 & 3.58 & 2.80 & 3.85 & 2.50 & 2.50 & 2.40 \\
\cline { 2 - 9 } $\begin{array}{c}\text { Consumption of } \\
\text { elbor, } \mathrm{mg} / \mathrm{g}\end{array}$ & $\begin{array}{c}\text { Mode } 2: t=1,0 \mathrm{~mm}, \\
V_{\text {det }}=0,1 \mathrm{~m} / \mathrm{min}, \text { liquid coolant }\end{array}$ & 9 & 5 & 5 & 5 & 4 & - & - \\
\cline { 2 - 9 } & $\begin{array}{c}\text { Mode } 3: t=0,03 \mathrm{~mm}, \\
V_{\text {det }}=6 \mathrm{~m} / \mathrm{min}, \text { liquid coolant }\end{array}$ & 8 & 6.80 & 6 & 6 & 6 & 5 & 5 \\
\hline
\end{tabular}

With deep grinding during the formation of the profile on the cutting edges of circles with a discontinuous surface, their specific wear is quite large. After the profiling of the cutting protrusions, the specific wear of the wheels has a constant value, and the wear process acquires the signs of stationary. In the interval of the 7-minute grinding period of the P6M5 steel at modes 1,2, 3, the average value of the specific wear of the disks with a discontinuous working surface is, respectively, equal to: $q_{1}=3.113 \mathrm{mg} / \mathrm{g}, q_{2}=5.600 \mathrm{mg} / \mathrm{g}, q_{3}=6.114 \mathrm{mg} / \mathrm{g}$.

When deep grinding with a continuous circle of KP 160/125 B8 100 at different modes after removing $75 \mathrm{~g}$ of metal, the average specific wear was $4.5 \mathrm{mg} / \mathrm{m}$.

The data presented indicate that with deep grinding, the specific wear of discontinuous circles is approximately the same as the specific wear of continuous circles and can only slightly differ depending on the regimes. However, the use of intermittent circles for deep grinding is more effective, since their specific wear is much less than with intermittent grinding in conventional modes with small grinding depths and high speeds of the part moving.

With a single-factor change in the mode parameters $t, V_{\text {cir }}, V_{u}$, the relative consumption of a diamond intermittent circle has an extremum. Deep intermittent diamond grinding can reduce the relative consumption of diamonds along with increased processing capacity [8].

$$
\alpha=\frac{0.343}{\beta_{1}^{0.5}\left(1-0.3 \cdot \beta_{1}^{1.25} \cdot \beta_{2}^{2.5} \cdot \beta_{3}^{2.5}\right)^{3}},
$$

where $\alpha=\frac{q}{q_{\min }} ; \beta_{1}=\frac{t}{t_{c d}} ; \quad \beta_{2}=\frac{V_{u}}{V_{w}} ; \beta_{3}=\left(1+\frac{l}{l_{1}}\right) /\left(1+\frac{l_{2}}{l_{1}}\right)_{c d}$;

$q_{\min }-$ minimum specific consumption of diamond intermittent circles;

$t_{c d}, V_{w},\left(1+\frac{l_{2}}{l_{1}}\right)_{c d}$ - cutting depth, workpiece speed and process discontinuity rate, at which the minimum specific consumption of the circle is observed $q_{\min }$. 
The dependence of the change on the parameter $\beta_{1}=0 \ldots 10$ at $\beta_{2}=0.6$ is shown in Fig. 8 . When grinding with a discontinuous circle $\left(1+\frac{l_{2}}{l_{1}}\right)=1.5$ with increasing parameter $\beta_{1} \leq 1$, the value of the function $\alpha$ decreases, and when $\beta_{1}>1$ increases. The dimensionless coefficient of process discontinuity $\beta_{3}$ significantly affects the specific consumption of diamonds. For example, with a change of $\beta_{3}$ from 1 to 1.5 (at $\beta_{1}=1$ ), the relative wear of the circles $\alpha$ increases from 0.457 to 0.753. In Fig. 8, the parameter takes the following values: $\beta_{3}=1$ (curve 1), $\beta_{3}=1.2$ (curve 2), $\beta_{3}=1.3$ (curve 3), $\beta_{3}=1.4$ (curve 4), $\beta_{3}=1.5$ (curve 5). Intensification of the process of intermittent diamond grinding should be carried out due to the increase in the parameter $\beta_{1}$ with decreasing by a certain law $\beta_{2}$.

Estimation of properties of elboric circles, which ensure their most effective use, can be made at the specific cost of processing. The dependence of the specific cost of grinding $C_{s}$ on the speed of rotation of the circle $V_{\text {cir }}$ has a parabolic form (that is, it has a minimum) [9]. Fig. 9 shows the graphs $C_{s}=f\left(V_{\text {cir }}\right)$ constructed for two discontinuous grinding wheels and having the same characteristics, the same values of the ratio of the extent of the depression to the length of the protuberance, but different amounts.

It can be seen from Fig. 9 that if you grind with circles that have 37 and 67 protrusions on the working surfaces with the same cutting speed $V_{c i r}=25 \mathrm{~m} / \mathrm{s}$, then the specific cost of machining with a circle with 37 projections will be twice as high as when grinding with 67 with cutting protrusions.

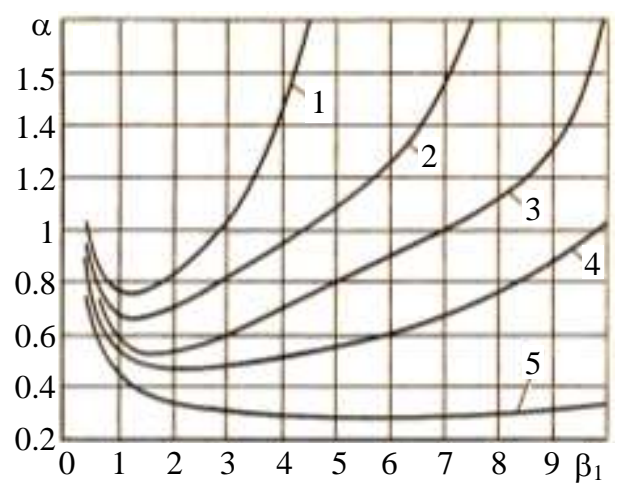

Fig. 8. Dependence of the change of $\alpha$ on the parameter $\beta_{1}=0 . . .10$ at $\beta_{1}=0.6$

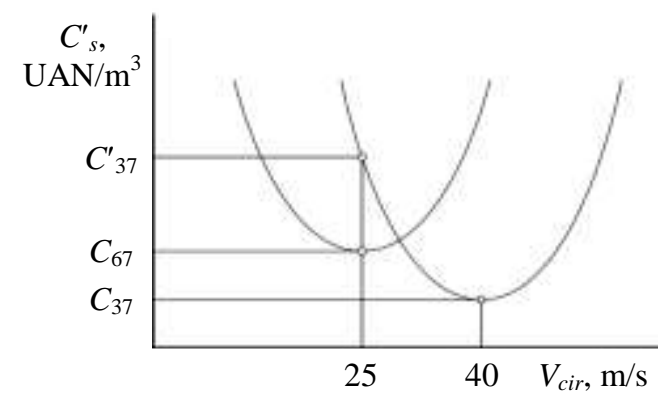

Fig. 9. Dependences of the specific cost of processing on the cutting speed when grinding by discontinuous circles having 37 and 67 cutting protrusions on the working surface (with the same ratio values $l_{2} / l_{1}$ )

When grinding with different cutting speeds $(25 \mathrm{~m} / \mathrm{s}$ and $40 \mathrm{~m} / \mathrm{s})$, it would be possible to achieve the opposite result when the specific cost of machining with a circle with 37 projections is half that of grinding with a circle with 67 projections. It is not always possible to determine the minimum value of the cost price of grinding only on the basis of the production experience of the technologist.

We also need analytical studies. Without appropriate calculations, grinding with a discontinuous circle with any number of slots on its working surface and with any value of the ratio of the extent of the cavity to the length of the protrusion will be carried out with a deliberately increased cost of processing.

The specific cost $C_{c}$ of the grinding process includes the costs of wages $C_{1}$, grinding wheel $C_{2}$ and electricity $C_{3}$. These costs are associated with the removal of $1 \mathrm{~m}^{3}$ of metal [10].

$$
C_{s}=C_{1}+C_{2}+C_{3}=\frac{S_{1} \cdot Z \cdot K}{Q}+\frac{P}{Q \cdot T}+S_{2} \cdot E,
$$


where $S_{1}$ - the tariff rate of the worker, $\mathrm{UAH} /$ hour;

$Z$ - coefficient that takes into account the proportion of auxiliary time for processing one part to the main time;

$K-$ a coefficient that takes into account all possible accruals on the wages of the worker;

$Q$ - processing capacity, $\mathrm{m}^{3} /$ hour;

$P$ - the price of one grinding wheel, UAH;

$T$ - period of resistance of the grinding wheel to its total wear, hour;

$S_{2}$ - cost of a unit of electricity, UAH;

$E$ - energy intensity of processing, $\mathrm{J} / \mathrm{m}^{3}$. $\left(\frac{\mathrm{kWt} \cdot \text { hour }}{\mathrm{m}^{3}}\right)$.

It can be seen from the expression (4) that the costs for the grinding wheel $\mathrm{B}_{2}$ are determined by its cost $P$, its cutting ability $Q$ and its resistance $T$. The cost of discontinuous circles having the same characteristics (material and size of the abrasive grains, type of bond, hardness and structure of the circle, height and diameter of the circle) is determined by the number and depth of the slots on its working surface. The deeper the slots and the more their number on the wheel, the higher its cost. The period of the resistance of the wheel to its total wear $T$ directly depends on the period of work of the wheel between the two corrections. Editing the wheel is necessary to restore its cutting properties and give it the correct geometric shape. Increasing the number of cavities on the grinding wheel creates the conditions for its self-sharpening. Self-sharpening consists in the fact that as a result of dying out of abrasive grains new sharp cutting edges appear, and with a sufficiently large dimensional wear, a new row of abrasive grains enters the work, which allows maintaining a high cutting ability of the wheel for a relatively long period of time. In other words, with increasing slits on the wheel, its resistance $T$ and cutting ability $Q$ increase.

The efficiency of the grinding wheel depends essentially on the cutting speed $V_{c i r}$. So, on the one hand, with increasing cutting speed, the contact time of the cutting protrusion with the surface to be treated decreases, which leads to a decrease in the proportion of heat entering the workpiece. On the other hand, the number of meetings of cutting grains with a ground surface increased per unit time, which leads to an increase in the grinding temperature.

In addition, an increase in cutting speed with intermittent grinding causes an increase in the kinetic energy of the impact of the cutting protrusion, which contributes to the continuous self-sharpening of the circle, an increase in the number of actively cutting grains, and an increase in grinding performance. Increased self-sharpening of the tool is not always justified when grinding.

On certain grinding operations, the necessary condition is to save the profile of the circle for a certain time. In these conditions, increasing the self-sharpening of the grinding wheel can lead to a decrease in the accuracy of the treatment.

It follows from the analysis of Fig. 2 and Fig. 9 that the cutting speed $V_{\text {cir }}$ exerts a significant influence on the parametric stability of the elastic system of the grinding machine and, consequently, on the quality and cost of manufacturing the parts.

The use of such machines will reduce the cost of processing $C$ by reducing the coefficient $Z$ in formula (4). However, in dependence (4) it is necessary to introduce a new term $C_{4}$, taking into account the costs of acquiring a new, more perfect machine.

$$
C_{4}=\frac{P_{m}}{n_{1} \cdot V}
$$

where $C_{4}$ - machine costs related to the removal of $1 \mathrm{~mm}^{3}$ of metal;

$P_{m}$ - the price of the grinding machine, $\mathrm{UAH}$;

$n_{1}$ - number of parts processed;

$V$ - the volume of metal removed when grinding the part, $\mathrm{mm} 3$. 
Results. Analyzing the terms $C_{1}, C_{2}, C_{3}, C_{4}$ for various types of abrasive processing, it is possible to reach optimal grinding conditions, grinding wheel characteristics, equipment, etc., i.e. to achieve the minimum cost price of grinding.

Thus, the specific prime cost of the grinding process depends on the cost and operating conditions of the intermittent circle. Forecasting the unit cost of processing should be based not only on the production experience of the technologist, but also on analytical studies.

Conclusions. Thus, we can name the following main ways to reduce the cost of grinding processing of products that affect the optimal grinding mode and ensure the quality of manufacturing parts:

- choice of the optimal technology for manufacturing discontinuous circles;

- reduction of tool wear and, correspondingly, increase in its durability;

- use of intermittent circles for deep grinding in order to increase the coefficient of intermittence and, accordingly, to reduce the number of depressions and protrusions in discontinuous circles;

- changing the cutting speed;

- use of modern grinding machines capable of maintaining the peripheral speed of rotation of the abrasive tool at a constant level.

According to the results of the conducted study, it can be said that the specific cost of the grinding process depends to a large extent on the cost and operating conditions of the intermittent circle. The forecasting of the specific cost price of processing should be based not only on the production experience of the technologist, but also on analytical studies.

\section{Література}

1. Стрелков В.Б. Определение себестоимости алмазного шлифования твердых сплавов при периодических электроэрозионных воздействиях на рабочую поверхность круга. Наукові праиі Донецького начіонального технічного університету. Серія: Машинобудування і машинознавство. 2005. Вип. 2. С. 109-117.

2. Феник Л.Н. Технологические методы повышения работоспособности алмазного инструмента. Донбас 2020 наука і техніка - виробництву : матеріали IV науково-практичної конференції (Донецьк, 27-28 травня 2008 року). Донецьк, 2008. С. 236-239.

3. Стрелков В.Б., Полтавец В.В., Цокур В.П. Влияние времени обработки на производительность алмазного шлифования по упругой схеме твердых сплавов группы ВК. Наукові праиі Донецького наиіонального технічного університету. Серія: Машинобудування і машинознавство. 2004. Вип. 1. C. $56-62$.

4. Полтавец В.В. Достижение максимальной производительности шлифования с учетом изменения режущих свойств круга. Прогрессивные технологии и системы машиностроения: международный сб. научных трудов. 2003. Вып. 24. С. 128-133.

5. Скуратов Д.Л., Трусов В.Н. Перспективные направления снижения энергетических затрат при шлифовании. Вестник СГАУ. 2008. №3. С. 59-65.

6. Худобин Л.В., Веткасов Н.И. Шлифование композиционными кругами. Ульяновск : УлГТУ, 2004. $256 \mathrm{c}$.

7. Гунько Н.И. Исследование влияния жесткости плоскошлифовального станка на износ абразивных кругов при прерывистом шлифовании. Числовые методы обработки : сб. науч. трудов. 1971. Вып. 97. С. 3-8.

8. Якимов А.А., Новиков Ф.В. Повышение эффективности алмазного прерывистого шлифования. Вестник машиностроения : ежемес. науч.-техн. и производ. журн. 1988. №7. С. 45-47.

9. Новиков Д.Ф., Оспищева А.К. Повышение конкурентоспособности машиностроительной продукции на основе снижения себестоимости металлообработки. Физические и компьютерные технологии : труды 19-й Междунар. науч.-техн. конф. Харьков : ХНПК ФЭД, 2014. С. 157-159.

10. Новіков Ф.В., Яценко Е.С. Економічний аналіз рівня технологічної підготовки виробництва. Физические и компьютерные технологии : труды 13-й Междунар. науч.-техн. конф. Харьков : ХНПК ФЭД, 2007. С. 594-597. 


\section{References}

1. Strelkov V.B. (2005). Determination of the cost price of diamond grinding of hard alloys with periodic electroerosive influences on the working surface of a circle. Scientific works of Donetsk National Technical University. Series: Mechanical engineering and machine science, 2, 109-117.

2. Fenik L.N. (2008). Technological methods of increasing the working capacity of a diamond tool. Donbass 2020 science and technology - production: materials IV scientific-practical conference (27-28 travnia 2008) (pp. 236-239). Donetsk.

3. Strelkov V.B., Poltavetc V.V., \& Tcokur V.P. (2004). Effect of treatment time on the performance of diamond grinding according to the elastic scheme of hard alloys of the VC group. Scientific works of Donetsk National Technical University. Series: Mechanical engineering and machine science, 1, 56-62.

4. Poltavetc V.V. (2003). Achieving maximum grinding performance, taking into account changes in the cutting properties of the circle. Progressive technologies and systems of mechanical engineering: international coll. scientific papers, 24, 128-133.

5. Skuratov D.L., \& Trusov V.N. (2008). Prospective directions for reducing energy costs during grinding. Bulletin of SSAU, 3, 59-65.

6. Khudobin L.V., \& Vetkasov N.I. (2004). Grinding with composite circles. Ulianovsk: UlGTU.

7. Gunko N.I. (1971). Investigation of the influence of the rigidity of a surface grinding machine on the wear of abrasive wheels with intermittent grinding. Numerical methods of processing: coll. sci. works, 97, 3-8.

8. Iakimov A.A., Novikov F.V. (1988). Increasing the efficiency of diamond intermittent grinding. Herald of Machine Building: Monthly. scientific-techn. and production. journal, 7, 45-47.

9. Novikov D.F., \& Ospishcheva A.K. (2014). Increase of competitiveness of machine-building production on the basis of reduction of the cost price of metal working. Physical and Computer Technologies: Proceedings of the 19th Intern. scientific-techn. conf. Kharkov: KhNPK FED, 157-159.

10. Novikov F.V., \& Yatsenko E.S. (2007). Economic analysis of the level of technological preparation of production. Physical and Computer Technologies: Proceedings of the 13th Intern. scientific-techn. conf]. Kharkov: KhNPK FED, 594-597.

Якімов Олексій Олександрович; Yakimov Olekcii, ORCID: 0000-0003-2096-4555

Задорожко Гліб Ігорович; Zadorozhko Glib, ORCID: 0000-0002-4128-8798

Бовнегра Любов Віталіївна; Bovnegra Liubov, ORCID: 0000-0003-0429-2816

Безнос Світлана Володимирівна; Beznos Svitlana Volodymyrivna, ORCID: 0000-0002-9735-9663

Балан Володимир Олександрович; Balan Volodymyr, ORCID: 0000-0001-6183-9633

Received December 05, 2017

Accepted April 26, 2018 